\title{
ARTEMISIA ANNUA L. EXTRACT: A NEW PHYTOPRODUCT WITH SOD-LIKE AND ANTITUMOUR ACTIVITY
}

\author{
ROXANA LIANA STAN ${ }^{1 \#}$, BOGDAN SEVASTRE ${ }^{2 \#}$, CORINA IONESCU $^{1}$, NELI K. OLAH ${ }^{3}$, \\ LAURA GRAȚIELA VICAȘ ${ }^{4 *}$, EMÖKE PÁLL ${ }^{2}$, CORINA MOISA ${ }^{4}$, DANIELA HANGANU ${ }^{5}$, \\ ALEXANDRA CRISTINA SEVASTRE-BERGHIAN ${ }^{6}$, SANDA ANDREI ${ }^{2}$, FLAVIA ROXANA \\ PRIPON-FURTUNA $^{3}$, IOAN MARCUS ${ }^{2}$, ADRIANA CORINA HANGAN ${ }^{7}$
}

${ }^{I}$ Department of Pharmaceutical Biochemistry and Clinical Laboratory, Faculty of Pharmacy, "Iuliu Hațieganu” University of Medicine and Pharmacy, 8 Victor Babeș Street, 400000, Cluj-Napoca, Romania

${ }^{2}$ Paraclinic/Clinic Department, Faculty of Veterinary Medicine, University of Agricultural Science and Veterinary Medicine, 3-5 Mănăștur Street, 400372, Cluj-Napoca, Romania

${ }^{3}$ SC PlantExtrakt SRL, Rădaia, 407059, Cluj, Romania and Department of Pharmaceutical Industry, Faculty of Pharmacy,

"Vasile Goldis, Western University, 86 L. Rebreanu Street, 310048, Arad, Romania

${ }^{4}$ Department of Pharmacy, Faculty of Medicine and Pharmacy, University of Oradea, 29 Nicolae Jiga Street, 410610,

Oradea, Romania

${ }^{5}$ Department of Pharmacognosy, Faculty of Pharmacy, "Iuliu Hațieganu” University of Medicine and Pharmacy, 8 Victor Babeș Street, 400000, Cluj-Napoca, Romania

${ }^{6}$ Department of Physiology, Faculty of Medicine, “Iuliu Hațieganu” University of Medicine and Pharmacy, 8 Victor Babeș Street, 400000, Cluj-Napoca, Romania

${ }^{7}$ Department of Inorganic Chemistry, Faculty of Pharmacy, "Iuliu Hațieganu” University of Medicine and Pharmacy, 8

Victor Babeș Street, 400000, Cluj-Napoca, Romania

*corresponding author: laura.vicas@gmail.com

${ }^{\#}$ Authors with equal contribution.

Manuscript received: November 2019

\begin{abstract}
The purpose of the present study was to investigate the antitumour potential of Artemisia annua L., harvested from Romania, Bihor area. Artemisinin, quercetin and galic acid have been identified using the LC-MS method. Hypothesis that Artemisia аппиа L. antitumour effect relays on the modulation of antioxidant activity of SOD has been tested using the SOD defective S. cerevisiae model. According to our results, Artemisia annua L. revealed a selective inhibitory effect on tumour cells of WM35 melanoma cell line in vitro, with a calculated $\mathrm{IC}_{50}$ three times lower as compared to normal HDF fibroblasts. Also, in vivo studies on Ehrlich carcinoma model revealed the amplification effect of Artemisia annua L. on the cytostatic effect of doxorubicin. On both in vivo and in vitro models, the inhibition of the tumour cell proliferation was associated with inhibition of the activities of antioxidative enzymes activities, thus antitumour effect of Artemisia апnиа L. might be related to oxidative alterations in malignant cells.
\end{abstract}

\section{Rezumat}

Scopul studiului a fost de a investiga potențialul antitumoral al Artemisiei annua L., plantă recoltată din Romania, județul Bihor. Artemisinina, quercetina și acidul galic au fost identificate prin analiză LC-MS. Utilizând S. cerevisiae, am testat ipoteza că efectul antitumoral al Artemisia annua L. este corelat cu modularea activității antioxidante a SOD. In vitro, pe linia celulară de melanom (WM35), Artemisia annua L. a inhibat selectiv celulele tumorale, IC $_{50}$ fiind de trei ori mai scăzut decât pentru fibroblastele normale (HDF). Studiile in vivo pe carcinomul ascitic Ehrlich au indicat faptul că Artemisia annua L. potențează efectul citostatic al doxorubicinei. Atât in vivo cât și in vitro, inhibarea proliferării tumorale a fost corelată cu inhibarea activității enzimelor antioxidante, astfel efectul antitumoral al Artemisia annua L. poate fi în legătură cu alterările oxidative de la nivelul celulelor tumorale.

Keywords: antitumour, artemisinin, Ehrlich carcinoma, phytoproduct

\section{Introduction}

Cancer is one of the major causes of death in the world, representing the second cause of mortality after cardiovascular diseases [13].

One of the most used methods for cancer treatment is the well-known chemotherapy, although, due to the non-selectivity of medicines, a high percentage of healthy cells are lost together with the cancer ones. That is exactly why, the most important problem in the cancer treatment remains destroying the tumour cells in the presence of healthy, normal ones, without harming the latter. In order to prepare anticancer medicines from natural resources, screening raw extracts 
of plants and testing cytotoxic compounds eventually present is necessary [21].

Artemisia annua L. (Asteraceae) is an annual herb of Asian origin, used for many centuries in the traditional Asian medicine for the treatment and prevention of fever and chills. A variety of compounds have been already extracted from Artemisia annua L. such as sesquiterpenoids, flavonoids, coumarins, lipids, phenolics, purines, steroids, triterpenoids, aliphatics and artemisinin [12]. The main component in Artemisia annua L. is artemisinin. Artemisinin has been widely used for the treatment of malaria for the past two decades. Additionally, artemisinin is known to exhibit antibacterial, antifungal, antileishmanial, antioxidant, antitumour and anti-inflammatory activities [7, 26]. Artemisinin has been tested on many different types of human cancer cell lines, as follows: MCF-7, MDA-MB-231 (breast cancer) [29]; H22, $\mathrm{HepG}_{2}$, Huh-7 (hepatoma) [30]; CCRF-CEM (leukaemia); GLC4 (lung cancer) [14]; CNE-1, CNE-2 (nasopharyngeal cancer) [33] and LNCaP (prostate cancer) [32]. Unfortunately, only a small number of studies had simultaneously tested the compound on both normal and cancerous cells as well. In general, artemisinin proved to be more toxic toward cancer cells than through normal cells [14]. Flavonoids can potentially enhance the anticancer effect of artemisinin by increasing its bioavailability and serum half-life, inhibiting metabolic enzymes, increasing the cellular $\mathrm{Fe}^{2+}$ level by reduction of $\mathrm{Fe}^{3+}$ and by affecting levels of pro-apoptotic and anti-apoptotic proteins in cancer cells [7].

Artemisia аппиа L. has gained increasing attention for the anticancer activities assigned to its compounds. In general, less is known about Artemisia annua L. extracts even though there are some positive case reports about the application of Artemisia annua L. extracts marketed as herbal preparations in people and pets suffering from malignant diseases $[1,5]$. For example, the cytotoxicity of an ethanolic extract of Artemisia annua L. to molt-4 human leukaemia cells was studied [25].

Therefore, availability of natural products with higher effectiveness and lower side effects is continuously desired. Medicinal herbs are important for the cancer treatment, due to their composition made of multiple chemical compounds, serving for the discovery of new active cytotoxic materials. In this context, our group of researchers has previously reported several studies demonstrating the in vitro/in vivo antioxidant and antitumour activities for Viscum album [27], Euonymus europaeus [23, 24], Centaurea cyanus, Calendula officinalis [17], Salvia officinalis and Verbascum phlomoides [16].

The first objective of the present study was the artemisinin, quercetin and gallic acid evaluation using LC methods, from Artemisia аппиа L. extract, plant harvested from Romania, Bihor area. The second objective was to demonstrate it's in vitro SOD like-activity and in vitro/in vivo antitumour activity. After that, we aimed to obtain a new phytoproduct that can be used in prevention or/and combined therapy of cancer.

\section{Materials and Methods}

\section{Plant material}

Artemisia annua L. herb was harvested in July 2017, from Bihor County, Romania. The plant harvest was performed according to the Good Agricultural and Collection Practices rules, from an unpolluted area. Botanical identification on vegetal raw material was performed in the SC PlantExtrakt SRL's quality control laboratory. In the laboratory herbarium, a voucher specimen (no. 7096/2017) has been kept. According to the Romanian Pharmacopoeia, $10^{\text {th }}$ edition, the vegetal product was dried in an oven at $40^{\circ} \mathrm{C}$ for total moisture removal and then was crushed (passing through the sieve number I) [6].

Extract preparation

The dried Artemisia annua L. herb was extracted with $70 \%$ vol. ethanol. The extraction ratio was 1 part of plant to 5 parts of solvent and was performed at room temperature, by cold extraction, using a magnetic stirrer. The extraction was done by mixing the plant-solvent mixture for 2 hours. Then the extract was filtered through qualitative paper. For the LC analysis, the obtained hydroalcoholic extract was diluted 1 to 10 with the initial mobile phase mixture [11].

Artemisinin, quercetin and gallic acid evaluation using LC methods

The LC analysis was performed using a Shimadzu Nexera-i LC-2040Plus 3D plus HPLC system equipped with a quaternary pump, autosampler and DAD detector, respectively a Shimadzu LCMS-8045 UPLC-MS system with ESI probe and quadrupole rod mass spectrometer. The identity of the separated compounds was performed with Shimadzu LCMS-8045 UPLC-MS system using a Fortis C18 column (150 mm x $2.1 \mathrm{~mm} \times 3 \mu \mathrm{m})$. A gradient with acetonitrile, water and $0.1 \%$ formic acid was used as mobile phase, with a flow rate of 0.5 $\mathrm{mL} / \mathrm{min}$. The mass spectrometer was used in positive ionization mode for artemisinin and quercetin, respectively in negative ionization mode for gallic acid. The $m / z$ 's were recorded from 80 to 350 . Both sample and standards were injected in a volume of $1 \mu \mathrm{L}$. In order to identify the compounds, the main fractions from MS spectra of standards and samples have been compared.

The HPLC-DAD analysis was performed in the same conditions. The detection was performed at $263 \mathrm{~nm}$ for artemisinin, $370 \mathrm{~nm}$ for quercetin and $272 \mathrm{~nm}$ for gallic acid. This analysis was performed for the quantitative determination of the identified compounds. For this reason, calibration curves were built from all three standards, using concentrations of 0.5 to $5.0 \mathrm{mg} / \mathrm{mL}$ for artemisinin, and 0.01 to $0.20 \mathrm{mg} / \mathrm{mL}$ for quercetin and gallic acid, respectively. 
The $70 \%$ vol. ethanol was prepared from $96 \%$ vol. ethanol from Coman Prod, Ilfov, Romania and ultrapurified water was obtained using a Simplicity UV system, Millipore-Merck, USA. The acetonitrile and formic acid were purchased from Merck, Germany and the standards from Sigma-Aldrich, USA (gallic acid and artemisinin), respectively Phytolab, Germany (quercetin).

In vitro $S O D$-like activity

The protective effect of Artemisia annua L. hydroalcoholic extract against free radicals produced by oxidative agents has been determined.

The SOD-like activity of the plant extract was evaluated using a strain of $S$. cerevisiae $\Delta$ sod1 (ATCC96687) (American Type Culture Collection), with the ability to delete/insert the $\mathrm{SOD}_{1}$ gene encoding the synthesis of $\mathrm{Cu}_{2} \mathrm{Zn}_{2} \mathrm{SOD}$. Yeast cells were grown in YPD reach medium ( $1 \%$ yeast extract, $2 \%$ peptone and $2 \%$ glycerol). Solid media contained $1.5 \%$ agar. Solutions of the liophilized extract in a mixture of DMSO:EtOH (1:4) at increasing concentrations $(10,30,50 \mu \mathrm{g} / \mathrm{mL})$ were added to the growth medium. Cell suspensions were poured into Petri dishes and allowed to solidify at room temperature. Paper disks measuring $6 \mathrm{~mm}$ in diameter (Antibiotica test Blättchen) containing $5 \mu \mathrm{L}$ of a $5 \mathrm{mM}$ menadione solution in ethanol or $5 \mu \mathrm{L}$ of $17.5 \% \mathrm{H}_{2} \mathrm{O}_{2}$ have been used. The diameters of clear zones around the disks, measured after 3 days of incubation at $28^{\circ} \mathrm{C}$, where taken as a quantitative estimate of the protective action [16].

Cell culture

The assessment of the antiproliferative effect was performed both on human normal primary fibroblasts HDFa and on WM35, a human radial growth phase melanoma cell line (ATCC Manassas, Virginia, USA). HDFa cells have been cultivated in DMEM medium (Dulbecco's modified Eagle's medium) supplemented with $5 \%$ foetal calf serum (FCS, Hyclone), $50 \mu \mathrm{g} / \mathrm{mL}$ gentamicin and $5 \mathrm{ng} / \mathrm{mL}$ amfotericin (Biochrom $\mathrm{Ag}$, Berlin, Germany). WM35 cells were maintained in RPMI medium (Sigma-Aldrich), supplemented with $10 \%$ foetal calf serum (FCS, Hyclone), $50 \mu \mathrm{g} / \mathrm{mL}$ gentamicin and $5 \mathrm{ng} / \mathrm{mL}$ amfotericin (Biochrom $\mathrm{Ag}$ ). The cultures were maintained in a humidified atmosphere with $5 \% \mathrm{CO}_{2}$ at $37^{\circ} \mathrm{C}$.

Cell toxicity assay

The cell cytotoxicity assay was performed using 3(4,5-dimethylthiazol-2-yl)-2,5-diphenyltetrazolium bromide (MTT test) (CellTiter $96{ }^{\circledR}$ Aqueous NonRadioactive Cell Proliferation Assay, Promega Corporation Madison, USA), as specified by the manufacturer. An ELISA microplate reader was used (Tecan, Männedorf, Switzerland). The cultures were then exposed to Artemisia annua L. hydroalcoholic extract in increasing concentrations, ranging from 0.05 to $50 \mu \mathrm{g} / \mathrm{mL}$, for 24, 48 and 72 hours. Initially, a stock solution of the extract containing $0.3 \%$ DMSO was prepared. Each experiment was carried out in triplicate. Cell cultures treated only with medium were used as controls. At the end of the incubation period, the treated cells and their control counterpart were incubated for 2 hours with $200 \mu \mathrm{L}$ of MTT. The formazan was solubilized with $200 \mu \mathrm{L}$ DMSO and the absorbance of each sample was read at $550 \mathrm{~nm}$, using an ELISA microplate reader. The $\mathrm{IC}_{50}$ values representing the extract concentration required to inhibit $50 \%$ of cell proliferation were calculated from the calibration curve by nonlinear regression using GraphPad Prism version 5.0 for Windows, GraphPad Software, San Diego California USA [9, 10].

In vivo antitumour activity

The experiments on animals were performed according to the EU Directive 2010/63 and National low no. 43/11.04.2014, into the Establishment for the breeding and use for laboratory animals of the "Iuliu Haţieganu" University of Medicine and Pharmacy Cluj-Napoca, Romania. The experiment was approved by the Bioethical Board of "Iuliu Haţieganu" University, and authorized by the State Veterinary Authority. The animals were caged in polycarbonate cages, at controlled temperature (of $21-22^{\circ} \mathrm{C}$ ), humidity (40 $60 \%$ ) and 12/12 h light/dark cycle. Standard lab chow, provided by the "Cantacuzino" National Institute for Research and Development (Bucharest), and water were freely available.

For a subacute toxicity test, 10 adult Mus musculus, $27.15 \pm 2.03 \mathrm{~g}$ body weight, 5 males and 5 females have been used. During a period of 14 days, all animals received daily Artemisia annua L. extract in a dose of $1000 \mathrm{mg}$ dry substance (d.s.)/kg b.w. The body weight and general clinical status were daily recorded. At the end, blood samples were collected from the orbitary sinus under deep narcosis, and then the animals were euthanized by narcotic overdose. Gross examination has been performed immediately after, and fragments of kidney and liver were removed, fixed in buffered formalin and embedded in paraffin wax. Later, the haematoxylin eosin stain has been performed for the histopathological examination, using an Olympus 1 CX41 optical microscope. Blood samples served to perform the biochemical and haematological examinations. Blood haematology (complete blood count) was investigated with Abacus Junior Vet, Diatron, 3 Diff Messtechnik, Hungary. Blood biochemistry (urea, creatinine and transaminase) was determined using screen point semiautomatic analyser, STAT - FAX 1904 Plus, Global Medical Instrumentation, Inc. 6511 Bunker Lake Blvd. Ramsey Minesota, 55303 USA, and special determination kits (Diagnosticum Zrt., Hungary). No toxicity in vivo was found.

Antitumour activity

Mus musculus female mice with a body weight about $26.88 \pm 1.11 \mathrm{~g}$ have been used. The mice were organized in four equal groups of eight mice and treated as follows. Group I - normal control group, receiving $50 \mathrm{mg}$ d.s. Artemisia annua L./b.w., intraperitoneally 
in the $1^{\text {st }}, 3^{\text {rd }}$ and $6^{\text {th }}$ day, in $0.5 \mathrm{~mL}$ sterile saline solution per animal. The dose has been established following preliminary toxicity studies. Group II tumour control group (EAC). Mice implanted with Ehrlich ascites carcinoma cells, $10^{6}$ ascitic cells each, on day 0 , and placebo therapy intraperitoneally $(0.5 \mathrm{~mL}$ saline physiological solution/mice, i.p). Group III - EAC and doxorubicin administration. Accordingly to the manufacturer specification, the $\mathrm{LD}_{50}$ for doxorubicin chloride, for mice, intraperitoneally administered, is $21.9 \mathrm{mg} / \mathrm{kg}$. The normal therapeutically dose being approximately 10 times lower, during the present experiment, mice received $2.5 \mathrm{mg}$ doxorubicin chloride/ b.w. (Adriblastina $10 \mathrm{mg}$, Pfizer) dissolved in sterile saline solution, up to $0.5 \mathrm{~mL}$ per animal. The mentioned doses were administered in the $1^{\text {st }}$ and the $6^{\text {th }}$ day of the experiment. Group IV - EAC and doxorubicin + Artemisia annua L. administration. Doxorubicin was administered under the same conditions. $50 \mathrm{mg}$ d.s. Artemisia annua L./b.w. was administrated intraperitoneally in the $1^{\text {st }}, 3^{\text {rd }}$ and $6^{\text {th }}$ day, in $0.5 \mathrm{~mL}$ sterile saline solution per animal.

14 days after EAC implantation, blood samples were collected by retro-orbital puncture under slight anaesthesia condition, then, euthanasia was induced by prolonged narcosis.

Analysis of tumour growth parameters

The volume of ascitic fluid from the peritoneal cavity was collected and measured with a syringe, immediately after euthanasia, and transferred in phosphate buffer

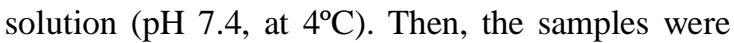
subjected to repeated centrifugations (at $4^{\circ} \mathrm{C}$ ), first at $4500 \mathrm{rpm}, 5 \mathrm{~min}$, then at $12000 \mathrm{rpm}, 3 \mathrm{~min}$, in order to obtain a dense cell suspension, which was also stored at deep freezer until further use.

The tumour cell concentration was counted in a Burker chamber (dilution 1:10) and the cell viability was assessed by Tripan blue staining ( $0.4 \%$ in PBS).

Body weight was measured at the beginning of the experiment, then in the days 3, 6, 9 and 12, and at the end of the study. The survival rate was $100 \%$ [22]. Activity determination of some enzymes involved in oxidative stress

Activity determination of some enzymes directly (SOD, CAT) and indirectly (XOD, Px) involved in oxidative stress, on WM35 melanoma cell line, in blood and EAC cells was performed using the corresponding assays kits (BioVision, USA), accordingly to the manufacturer specifications. A Specord 200 PLUS spectrophotometer has been used [3].

Statistics

All data are reported as means \pm SD. The Gaussian distribution was checked by the Shapiro-Wilk normality test. One-way analysis of variance ANOVA, followed by post hoc Dunnett's range test procedure was performed for pair-wise comparisons between the volume of ascitic fluid and variation of viable cells concentration, while the two-way ANOVA followed by the Bonferroni post-test was the choice for the variation of body weight. Statistical significance was at $\mathrm{p}<0.05$ (95\% confidence interval). Statistical values and figures were obtained using GraphPad Prism version 5.0 for Windows, GraphPad Software, San Diego California, USA.

\section{Results and Discussion}

Artemisinin, quercetin and gallic acid evaluation using LC methods

Under the above described LC conditions, gallic acid was separated at $1.20 \mathrm{~min}$, quercetin at $4.48 \mathrm{~min}$ and artemisinin at $6.53 \mathrm{~min}$, respectively. We have noticed the separation of the components from the extract at the same retention time. An overlapping of the main fractions in the MS spectra has been observed and upon this we could identify in the Artemisia аппиа L. hydroalcoholic extract, the three compounds of interest.

The quantitative determinations show that Artemisia annua $\mathrm{L}$. hydroalcoholic extract sample contains 82.90 $\mathrm{mg} / \mathrm{mL}$ artemisinin and $0.02 \mathrm{mg} / \mathrm{mL}$ quercetin. The gallic acid was found to be in traces, being identified only qualitatively, its content being under the lowest determination limit of the HPLC method. In vitro $S O D$-like activity

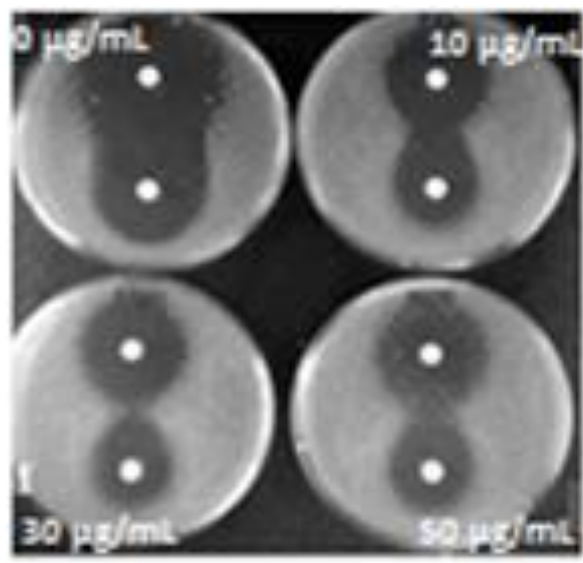

Figure 1.

Effect of Artemisia annua L. hydroalcoholic extract on the growth of the $\Delta$ sod1 mutant against free radicals produced by $\mathrm{H}_{2} \mathrm{O}_{2}$ (disk at the top of each Petri disk) and menadione (disk at the bottom of each Petri disk)

The in vitro SOD-like activity of the liofilizated extract was quantified by means of the method based on the protection against free radicals provided by the extract to the yeast $S$. cerevisiae [8]. The SOD-mimetic activity of the plant extract on cell growth with a $\Delta$ sodl mutant treated with menadione or $\mathrm{H}_{2} \mathrm{O}_{2}$ has been evaluated. The oxidative stress was produced by two oxidative agents: menadione which toxicity is due to the superoxide radical production (disk at the bottom 
of each Petri disk) and $\mathrm{H}_{2} \mathrm{O}_{2}$ which toxicity is registered due to $\mathrm{OH} \bullet$ radicals (disk at the top of each Petri disk). It will be considered that the extract has a SOD-like activity, if a decrease of the diameter of the inhibition zone will be registered versus the control zone. The efficacy will then be evaluated by comparison of the diameter of the inhibition area for the extract and control (Figure 1).
In the presence of the plant extract at concentrations of 10,30 and $50 \mu \mathrm{g} / \mathrm{mL}$ respectively, a significant reduction of the inhibition area has been observed, under oxidative stress conditions produced by both menadione and $\mathrm{H}_{2} \mathrm{O}_{2}$.

The diameter of the inhibition area for the extract in different concentrations, using menadione and $\mathrm{H}_{2} \mathrm{O}_{2}$ are given in Table I.

Table I

The diameter of inhibition area for the extract, in different concentrations, using menadione and $\mathrm{H}_{2} \mathrm{O}_{2}$

\begin{tabular}{ccc}
\hline $\begin{array}{c}\text { Extract } \\
(\boldsymbol{\mu} \mathbf{g} / \mathbf{m L})\end{array}$ & \multicolumn{2}{c}{$\begin{array}{c}\text { Artemisia annua } \mathbf{L} \text { hydroalcoholic extract } \\
\text { Diameter of the inhibition area }(\mathbf{c m})\end{array}$} \\
\cline { 2 - 3 } & Menadione & $\mathbf{H}_{\mathbf{2}} \mathbf{O}_{\mathbf{2}}$ \\
\hline Control (Menadione $5 \mathrm{mM}$ or $\mathrm{H}_{2} \mathrm{O}_{2}$ 17.5\%) & 8 & 7.5 \\
10 & 5 & 5.2 \\
30 & 4.6 & 5 \\
50 & 4.5 & 4.9 \\
\hline
\end{tabular}

Table II

$\mathrm{IC}_{50}$ values of Artemisia annua L. and doxorubicin on radial growth phase melanoma cell line (WM35) and human dermal fibroblasts (HDF) cells (versus untreated cells) (mean $\pm \mathrm{SD})(\mathrm{n}=3)$

\begin{tabular}{|c|c|c|c|c|}
\hline \multirow[t]{2}{*}{ Cells } & \multirow[t]{2}{*}{ Compound } & \multicolumn{3}{|c|}{$\mathrm{IC}_{50}(\mu \mathrm{g} / \mathrm{mL})$} \\
\hline & & $24 \mathrm{~h}$ & $48 \mathrm{~h}$ & $72 \mathrm{~h}$ \\
\hline WM35 cells & Artemisia annua $\mathrm{L}$. & $7.21 \pm 0.13$ & $3.55 \pm 0.35$ & $1.38 \pm 0.13$ \\
\hline & Doxorubicin & $1.40 \pm 0.05$ & $0.59 \pm 0.02$ & $0.26 \pm 0.01$ \\
\hline HDF cells & Artemisia аппиа $\mathrm{L}$. & $24.15 \pm 1.03$ & $9.19 \pm 0.04$ & $3.57 \pm 0.03$ \\
\hline & Doxorubicin & $2.94 \pm 1.05$ & $0.34 \pm 0.07$ & $0.16 \pm 0.02$ \\
\hline
\end{tabular}

The reduction of the inhibition area was between 38 44\% for the Artemisia annua L. hydroalcoholic extract against oxidative stress generated by menadione and in between 31 - 35\% against the oxidative stress generated by $\mathrm{H}_{2} \mathrm{O}_{2}$.

Considering the presented results, we observed that the protective activity of the extract does not seem to be dependent on the extract concentration and that the protection of the extract against free radicals generated by $\mathrm{H}_{2} \mathrm{O}_{2}$ is lower than in the case of free radicals generated by menadione.

The results suggest the potential of Artemisia annua L. hydroalcoholic extract to protect efficiently against superoxide anions; thereby we consider it as a promising effective agent against the toxicity they induce, improving significantly the growth of $\Delta s o d 1$ strain, by supplying the $\mathrm{Cu}_{2} \mathrm{Zn}_{2} \mathrm{SOD}$ deficiency of the mutant. Taking in account these results, we assume that the Artemisia аппиа L. hydroalcoholic extract may be considered as a potential therapeutic agent in the prevention and treatment of diseases mediated by free radicals. Cytotoxicity of Artemisia annua L. extract against WM35 cells

Human melanoma cell line (WM35) was compared to normal human dermal fibroblasts for sensitivity to Artemisia annua L. The dose-response curves showed that WM35 cells were more sensitive to Artemisia annua L. than normal fibroblasts (HDF cells), while doxorubicin indiscriminately inhibited both normal and tumour cells. The best difference was observed at $48 \mathrm{~h}$, when the $\mathrm{IC}_{50}$ values for HDF cells were $9.19 \pm 0.04 \mu \mathrm{g} / \mathrm{mL}$ for Artemisia annua L. and about only $0.34 \pm 0.07$ for doxorubicin, respectively. In tumour cells, the $\mathrm{IC}_{50}$ for Artemisia annua $\mathrm{L}$. was only six fold higher (Table II).

The activity of the antioxidant enzymes catalase (CAT), superoxide dismutase (SOD), xanthine oxidase (XOD) and peroxidase $(\mathrm{Px})$ from WM35 melanoma cell line is presented in Figure 2.

Previous studies have demonstrated that oxidative stress is clearly associated with carcinogenesis and the incidence of cancer. During the carcinogenesis process, the level or reactive oxygen species in cancer cells increases while the levels of defensive antioxidants agents dwindle.

There are three major types of antioxidant enzymes: SOD, CAT and Px. SOD is an antioxidant enzyme that converts superoxide anions $\left(\mathrm{O}_{2}{ }^{\circ}\right)$ into hydrogen peroxide $\left(\mathrm{H}_{2} \mathrm{O}_{2}\right)$. SOD actually has a dual role. First, it acts as an antioxidant because it eliminates superoxide anion, and secondly it acts as a pro-oxidant because it produces hydrogen peroxide [18]. The catalase and the peroxidase convert $\mathrm{H}_{2} \mathrm{O}_{2}$ into water. If $\mathrm{H}_{2} \mathrm{O}_{2}$ removal is inhibited, then direct toxicity results from $\mathrm{H}_{2} \mathrm{O}_{2}$ mediated damage [31]. Catalase is a primary antioxidant defence that converts $\mathrm{H}_{2} \mathrm{O}_{2}$ to water [20]. 

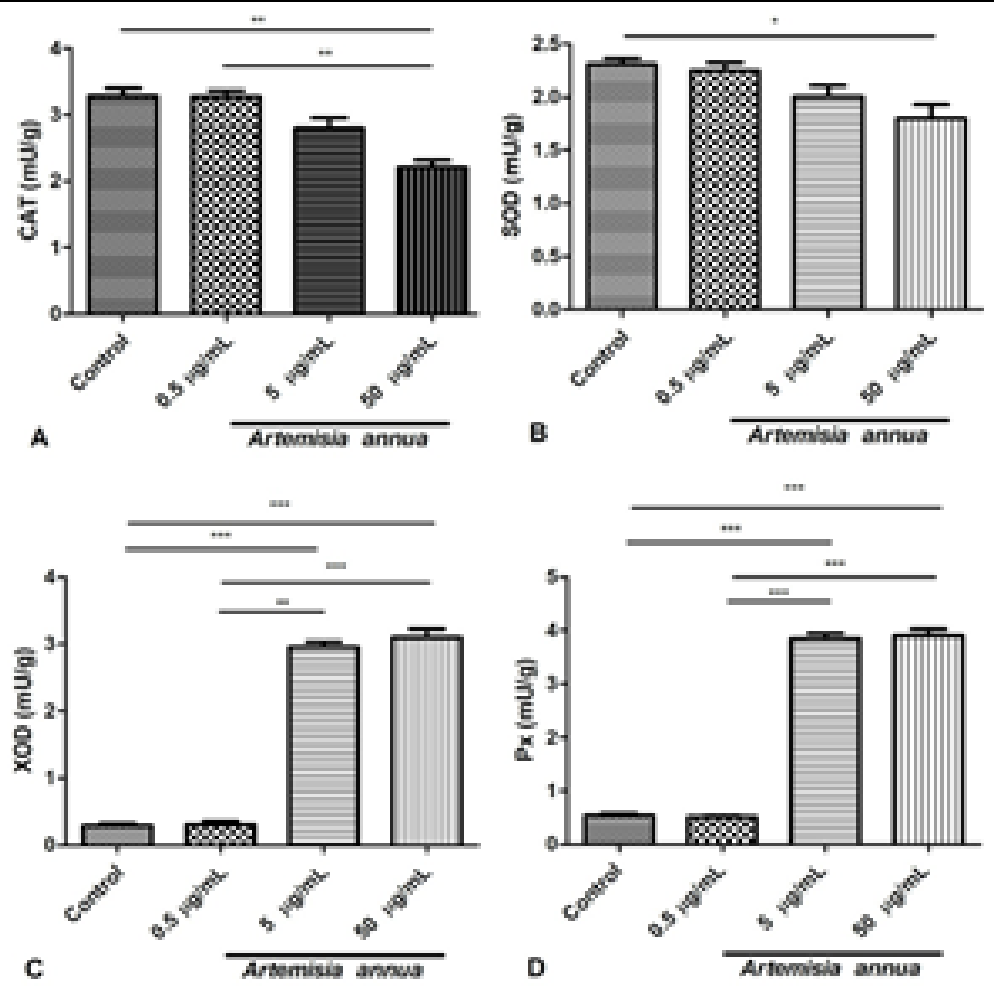

Figure 2.

Effects of Artemisia annua $\mathrm{L}$. in dose of $0.5,5$ and $50 \mu \mathrm{g} / \mathrm{mL}$ on antioxidant enzymes activities CAT (A), SOD

(B), XOD (C), Px (D) (mU/g) on melanoma cell line WM35 at 48 hours ( $v s$. untreated cells) $($ mean \pm SD) $(\mathrm{n}=3)(* \mathrm{p}<0.05 ; * * \mathrm{p}<0.01 ; * * * \mathrm{p}<0.001)$

According to our results, in WM35 tumour cells, Artemisia апnиa $\mathrm{L}$. induced alterations of the antioxidant systems only at a $5 \mu \mathrm{g} / \mathrm{mL}$ concentration. The effects consisted in diminishing the activity of the antioxidant enzymes, CAT and SOD, while increasing the activity of XOD and Px.

In cancer cells we have already found an increased oxidative stress. Artemisia annиa L. increases more the oxidative stress in the tumour cells because of artemisinin, the main constituent of Artemisia annua L., which is involved in the ROS production. ROS play a very key role in killing specific tumour cells, by inducing apoptosis and oxidative DNA damage. On the other hand, the increase of oxidative stress in tumour cells determine the increase of SOD and CAT levels, they normally being supposed to act as a defensive antioxidant system. Consequently, SOD decomposes the superoxide anions and CAT decomposes the hydrogen peroxide, meaning that their activity will decrease. With the decrease of SOD and CAT levels, the tumour cells are more susceptible to damage caused by ROS, thereby, strong oxidative stress may be an anticancer mechanism. The experimental results show that the Px are not involved in the hydrogen peroxide decomposition. So we assume that Px activity increases because it acts as a defensive antioxidant system.

These changes indicate an increased oxidative stress in tumour cells at concentrations at which the cytotoxic/antiproliferative effect is manifested. Therefore, the alteration of antioxidant capacity may be considered as a plausible cytotoxic and/or antiproliferative mechanism for the Artemisia апnиa L. extract.

Concerning the behaviour of the antioxidant enzymes in tumour cells, researchers' opinions are divided. For example, for the lung cancer some studies have shown increased antioxidant activities, others have reported reduced antioxidant activity [4].

In vivo antitumour activity

Analysis of tumour growth parameters

To demonstrate the in vivo antitumour effect of Artemisia annua $\mathrm{L}$. and the fact that the combined therapy Artemisia annua L. + doxorubicin increases the antitumour effect of doxorubicin, there have been determined as follows: the ascitic volume, the tumour cell concentration and the body weight gain for: the tumour control group (EAC), for the groups treated with doxorubicin alone after EAC inoculation and for the groups treated with combined therapy, doxorubicin + Artemisia аппиа $\mathrm{L}$.

A decrease has been found both in the ascitic volume (Figure 3A) and in the tumour cell concentration (Figure 3B) for both: EAC + doxorubicin and EAC + doxorubicin + Artemisia annиa L. groups as compared with the tumour control group (EAC). For the EAC + doxorubicin + Artemisia annua L. group, the ascitic volume was lower as compared to those of EAC + doxorubicin group. This demonstrated the effectiveness of combined therapy of Artemisia anпиа L. + doxorubicin. 

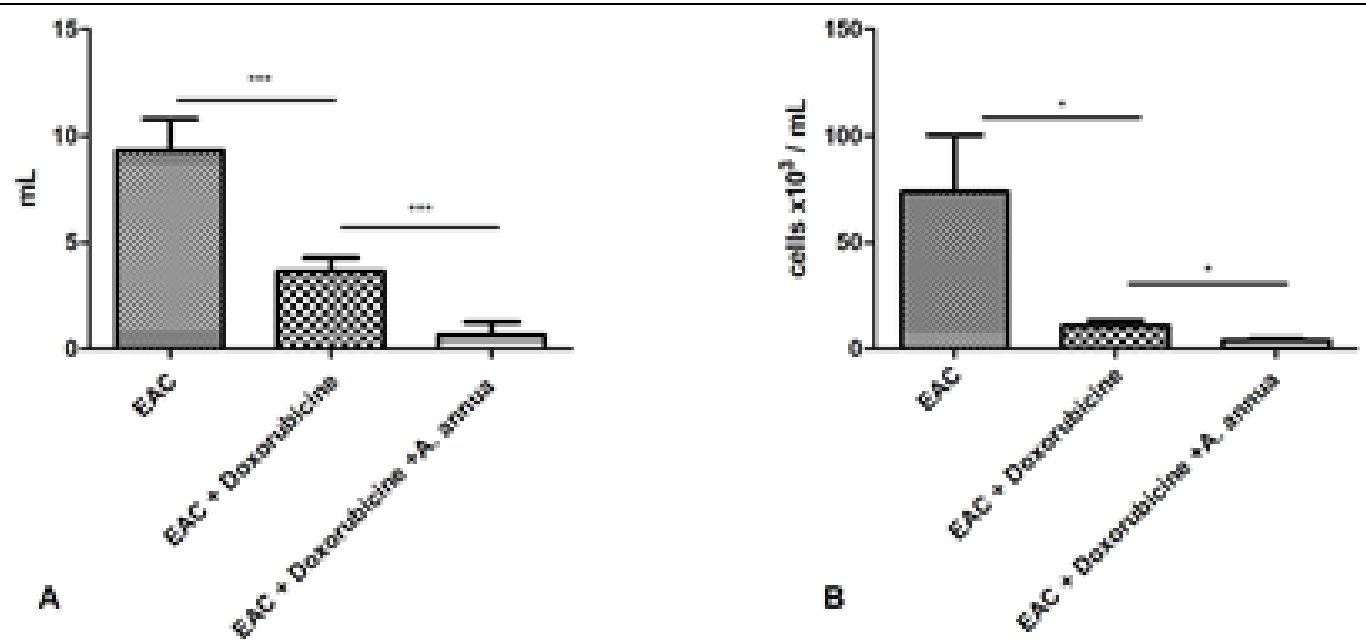

Figure 3.

Effects of doxorubicin therapy alone and of the combined therapy (Artemisia annua L. + doxorubicin) on ascitic volume $(\mathrm{mL})(\mathbf{A})$ and on tumour cell concentration $\left(\right.$ cells x $\left.10^{3} / \mathrm{mL}\right)(\mathbf{B})$

$(\mathrm{EAC}=$ tumour control group $)(* \mathrm{p}<0.05 ; * * * \mathrm{p}<0.001$ as compared to EAC group $)($ mean $\pm \mathrm{SD})(8$ animals/group $)$

The body weight gain, as a measure of Ehrlich ascites accumulation in the peritoneal cavity, is shown in Figure 4.

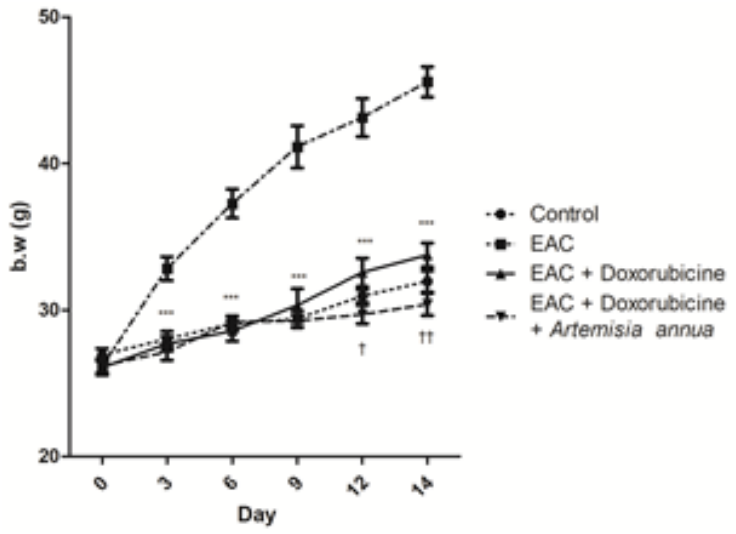

Figure 4.

Effects of doxorubicin therapy alone and of the combined therapy (Artemisia annua L. + doxorubicin) on the body weight gain ( $\mathrm{g}$ )

(EAC $=$ tumour control group) $(* * * \mathrm{p}<0.001$ as compared to EAC group; $\uparrow \mathrm{p}<0.05 ; \dagger \uparrow \mathrm{p}<0.01$ as compared to $\mathrm{EAC}+$ doxorubicin group) (mean $\pm \mathrm{SD})(8$ animals/group $)$

As expected, the ascites development was followed by the increase of the body weight. Both doxorubicin and doxorubicin + Artemisia annиa L. therapies prevented body weight gain. The differences were visible starting from the third day of the study. Both therapies provided significant protection, but better effect was found in the group treated with the combined therapy that we have experienced. The amount of ascitic fluid varied proportionally with the body weight gain. This demonstrated the effectiveness of the combined therapy of our proposed combined therapy.

The mechanism of action for doxorubicin is still unclear, but it is widely accepted an anti-proliferative mechanism based on the intercalation on DNA molecule, consequently blocking the DNA biosynthesis [28]. Also, the mechanism of action of artemisinin is still poorly understood. It has been found that cell membranes are the principal target sites. Artemisinin can not only induce apoptosis, but also plays a role in cellular necrosis. The main target is assumed to be the cell membrane, altered membrane metabolism leading to cell swelling. Once cytomembranes are destroyed, cells death results [15]. Furthermore, artemisinin can also induce apoptosis [14]: arrest the cell cycle particularly at the $\mathrm{G}_{0} / \mathrm{G}_{1}$ phases, inhibits angiogenesis, proliferation and migration of vascular endothelial cells and it seems to have also an effect on immune system functions [35].

Artemisinin belongs to the family of sesquiterpene lactones, with an endoperoxide bridge with great importance for its activity [35]. Although, the exact mechanism of action of artemisinin has not yet been fully elucidated, the C-radical hypothesis has become one of the most widely accepted theories. Throughout the whole process, the toxic-free radicals generated by the endoperoxide moiety of artemisinin via ferrous iron-mediated reaction are essential for killing or attenuating tumour cells. The peroxide bridge of artemisinin reacts with the ferrous atom and produce ROS. ROS play a very important role in killing specific tumour cells, for example, by inducing apoptosis and oxidative DNA damage. Due to the lack of antioxidant enzymes, the tumour cells are more susceptible to damage caused by ROS, and strong oxidative stress is the universal accepted mechanism of anticancer drugs. Compared with normal cells, cancer cells need a lot of iron involved in nucleic acid metabolism, while the majority of the surface of the tumour cells has a high density of transferrin receptor. Tumour cells with a high expression of transferrin receptor 
are more susceptible to artemisinin; therefore, the iron-rich cancer cells can stimulate cytotoxic effects of artemisinin [15, 19, 34].

The antimetastatic effects of artemisinin were associated with the expression of metalloproteinase genes and their effect on $\alpha v \beta 3$ integrins. Interestingly, the antimetastatic effect of artemisinin could be triggered by enhancing $\mathrm{Cdc} 42$ (protein involved in cell cycle regulation) and E-cadherin activation (protein involved in cell adhesion) [2].
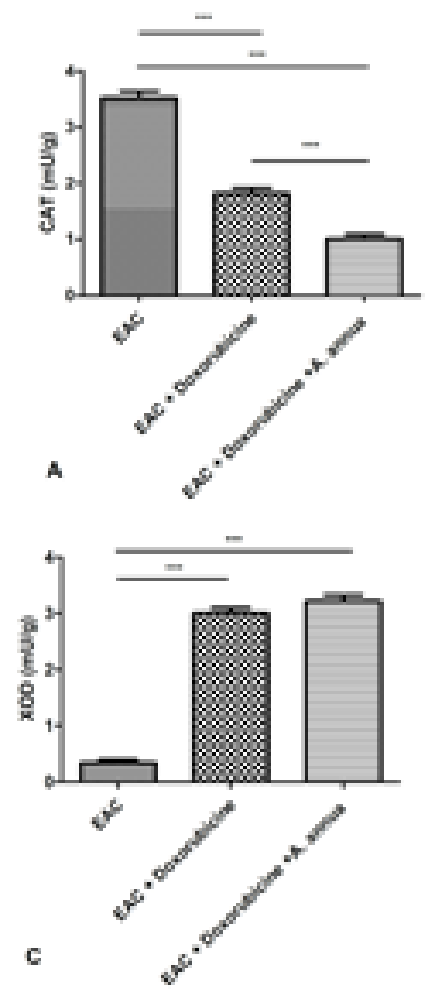

Activity determination of some enzymes involved in oxidative stress

The activity of the antioxidant enzymes (CAT, SOD, $\mathrm{XOD}, \mathrm{Px}$ ) in EAC cells is shown in Figure 5. Comparison was made for the antioxidant enzyme activities in the EAC group (tumour control) and the two groups treated after inoculation with doxorubicin alone, respectively, with doxorubicin + Artemisia annua $\mathrm{L}$.

\section{Figure 5.}

Effects of doxorubicin and doxorubicin + Artemisia annиa L. on tumour levels activities of oxidative stress related enzymes (mU/g): (A) CAT; (B) SOD; (C) XOD and (D) Px

$(\mathrm{EAC}=$ tumour control group $)(* * * \mathrm{p}<0.001$ as compared to $\mathrm{EAC}$ group $)$ (mean $\pm \mathrm{SD})(8$ animals/group)

As shown in the Figure 5, CAT and SOD activities had significantly decreased in both groups $(\mathrm{EAC}+$ doxorubicin and EAC + doxorubicin + Artemisia annua L.), while XOD and Px activities on the contrary, remained at high levels.

Antioxidant enzymes were examined in the blood samples of all experimental groups. Their antioxidant activity is presented in Figure 6.

In EAC free mice (control group), no changes in antioxidant enzymes activity were found. On the other hand, development of EAC was clearly associated with marked elevated enzymatic antioxidant activity (in tumour cells production of free oxygen radicals being normally increased). The EAC + doxorubicin and $\mathrm{EAC}+$ doxorubicin + Artemisia annua L. groups reacted as follows: all antioxidant enzymes activities were decreased as compared with the EAC group, although they remained higher than the control.

Significant differences occurred between EAC + doxorubicin + Artemisia annua L. vs. EAC + doxorubicin alone, demonstrating the intensification of the antioxidant effect following the combined therapy.

Overall, the results of the present study proved that the combined therapy of Artemisia annua L. + doxorubicin seems to provide a pronounced anti-proliferative effect as compared to doxorubicin alone. 

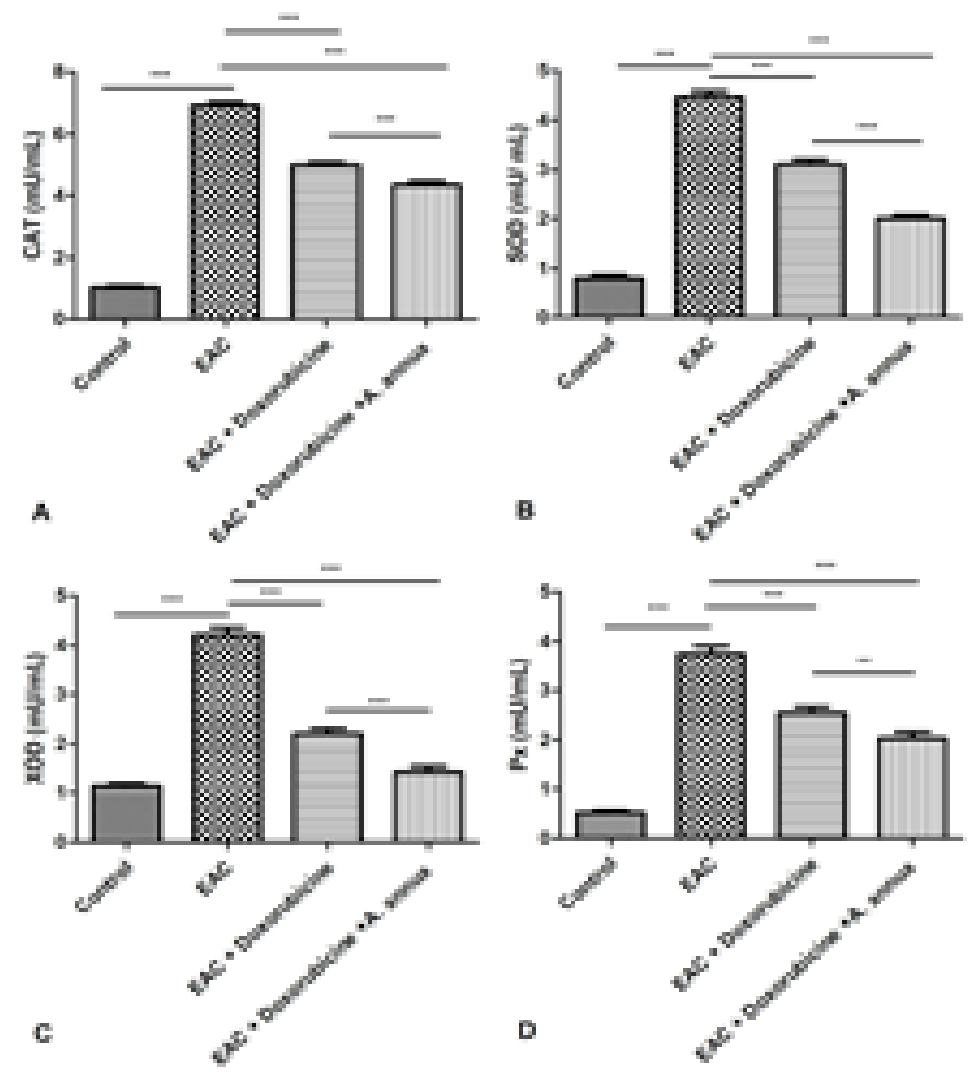

Figure 6.

Effects of doxorubicin and doxorubicin + Artemisia annua L. on blood levels activities regarding the oxidative stress related enzymes (mU/mL): (A) CAT; (B) SOD; (C) XOD and (D) Px

(EAC -tumour control group) $(* * \mathrm{p}<0.01, * * * \mathrm{p}<0.001)($ mean $\pm \mathrm{SD})(8$ animals/group)

\section{Conclusions}

Our study revealed the antioxidant/antitumoural activity of Artemisia annua L., as well as the fact that the combined doxorubicin + Artemisia annua L. therapy administered after EAC inoculation was more effective than doxorubicin administered alone under the same conditions. The Artemisia annua L. extract improved the antitumour effect, enhancing the antiproliferative effect of doxorubicin, so we believe that this combined therapy should be recommended. The results also suggest that Artemisia annua L. extract displays efficient protection against superoxide anions and for this reason it could be a useful, potential therapeutic agent in the prevention and treatment of diseases mediated by free radicals.

\section{Acknowledgement}

This study was funded by the Ministry of Research and Innovation through Program 1 - Development of the national research-development system, Subprogram 1.2 - Institutional performance - Funding projects for excellence in CDI. Financing contract no. 37 PFE/2018.

\section{Conflict of interest}

The authors declare no conflict of interest.

\section{References}

1. Breuer E, Efferth T, Treatment of iron-loaded veterinary sarcoma by Artemisia апnиa. Nat Prod Bioprospect., 2014; 4(2): 113-118.

2. Cavallo F, De Giovani C, Nanni P, Forni G, Lollini PL, The immune hallmarks of cancer. Cancer Immunol Immunother., 2011; 60(3): 319-326.

3. Cebovic T, Spasic S, Popovic M, Cytotoxic effects of the Viscum album L. extract on Ehrlich tumor cells in vivo. Phytother Res., 2008; 22(8): 1097-1103.

4. Cjung-man Ho J, Zheng S, Comhair SAA, Farver C, Erzurum SC, Differential expression of manganese superoxide dismutase and catalyse in lung cancer. Cancer Res., 2001; 61(23): 8578-8585.

5. Efferth T, From ancient herb to modern drug: Artemisia annua and artemisinin for cancer therapy. Semin Cancer Biol., 2017; 46: 65-83.

6. Romanian Pharmacopoeia, 2008, $X^{\text {th }}$ edition, Medical Publishing House, Bucharest, (available in Romanian).

7. Ferreira JF, Luthria DL, Sasaki T, Heyerick A, Flavonoids from Artemisia аппиа L. as antioxidants and their potential synergism with artemisinin against malaria and cancer. Molecules, 2010; 15(5): 3135-3170.

8. Gonzalez-Alvarez M, Alzuet G, Borras J, del CastilloAgudo L, Montejo-Bernardo JM, Strong protective action of copper (II) N-substituted sulfonamide complexes against reactive oxygen species. J Inorg Biochem., 2004; 98(2): 189-198. 
9. Hangan AC, Turza A, Stan RL, Sevastre B, Páll E, Cetean S, Oprean LS, Synthesis, crystal structure and characterization of new biologically active $\mathrm{Cu}$ (II) complexes with ligand derived from $\mathrm{N}$-substituted sulfonamides. J Chem Sci., 2016; 128(5): 815-824.

10. Hangan AC, Stan RL, Turza A, Oprean LS, Pall E, Gheorghe-Cetean S, Sevastre B, Synthesis, crystal structures, characterization and antitumor activities of two copper(II) complexes of a sulfonamide ligand. Transit Met Chem., 2017; 42(2): 153-164.

11. Hanganu D, Olah NK, Pop CE, Vlase L, Oniga I, Ciocîrlan N, Matei A, Pușcaș CM, Silaghi-Dumitrescu $\mathrm{R}$, Benedec D, Evaluation of polyphenolic profile and antioxidant activity for some Salvia sp., Farmacia, 2019; 67(5): 801-805.

12. Kim WS, Choi WJ, Lee S, Kim WJ, Lee DC, Sohn UD, Anti-inflamatory, antioxidant and antimicrobial effects of artemisinin extracts from Artemisia аппиа L. Korean J Physiol Pharmacol., 2015; 19(1): 21-27.

13. Kooti W, Servatyari MD, Behzadifar M, Asadi-Samani M, Sadeghi F, Effective medicinal plant in cancer treatment, Part 2: Review study. J Evid Based Complementary Altern Med., 2017; 22(4): 982-995.

14. Lai HC, Singh NP, Sasaki T, Development of artemisinin compounds for cancer treatment. Invest New Drugs, 2013: 31(1): 230-246.

15. Li Z, Li Q, Wu J, Wang M, Yu J, Artemisinin and its derivatives as a repurposing anticancer agent: what else do we need to do?. Molecules, 2016; 21(10): E1331: 1-14.

16. Marian E, Vicaș LG, Jurca T, Mureșan M, Pallag A, Stan RL, Sevastre B, Diaconeasa Z, Ionescu CML, Salvia offcinalis L. and Verbascum phlomoides L.: chemical, antimicrobial, antioxidant and antitumor investigations. Rev Chim (Bucharest), 2018; 69(2): 365-370.

17. Marian E, Vicaș LG, Jurca T, Mureșan M, Stan RL, Sevastre B, Diaconeasa Z, Ionescu C, Hangan A, A comparative study on the biological activity of Centaurea cyanus versus Calendula officinalis. Farmacia, 2017; 65(6): 940-946.

18. Nourazarian AR, Kangari P, Salmaninejad A, Roles of oxidative stress in the development and progression of breast cancer. Asian Pac J Cancer Prev., 2014; 15(12): 4745-4751.

19. Ooko E, Saeed MEM, Kadioglu O, Sarvi S, Colak M, Elmasaoudi K, Janah R, Greten HJ, Efferth T, Artemisinin derivatives induce iron-dependent cell death (ferroptosis) in tumor cells. Phytomedicine, 2015; 22(11): 1045-1054.

20. Jurca T, Pallag A, Marian E, Mureșan ME, Stan RL, Vicaş LG, The histo-anatomical investigation and the polyphenolic profile of antioxidant complex active ingredients from three Viola sp.. Farmacia, 2019, 67(4): 634-640.

21. Rafieian-Kopaie M, Nasri H, On the occasion of World Cancer Day 2015: the possibility of cancer prevention or treatment with antioxidants: the Ongoing Cancer Prevention Researches. Int J Prev Med., 2015; 108(6): 1-5.

22. Sarpataki O, Stan RL, Hangan AC, Olah NK, SevastreBerghian AC, Benedec D, Hanganu D, Sevastre B, Marcus I, Anticancer activity of Euonymus europaeus fruit extract on transplantable mouse tumor model. Bull UASVM, Vet Med., 2016; 73(1): 161-168.

23. Sevastre B, Sárpataki O, Stan RL, Taulescu M, SevastreBerghian AC, Olah NK, Furtuna F, Hanganu D, Hangan AC, Cenariu M, Bâldea I, Anticancer activity of Euonymus europaeus fruit extract on human melanoma cells. Farmacia, 2017; 65(1): 56-62.

24. Sevastre B, Sarpataki O, Olah NK, Stan RL, Taulescu M, Marcus I, Cătoi C, Anti-tumor effect of Euonymus europaeus on Ehrlich tumor cells in vivo. Farmacia, 2014; 62(5): 907-917.

25. Singh NP, Ferreira JFS, Park JS, Lai HC, Cytotoxicity of ethanolic extracts of Artemisia annua to molt-4 human leukemia cells. Planta Med., 2011; 77(16): 1788-1793.

26. Stan RL, Sevastre B, Hangan AC, Bota S, Hanganu D, Ionescu CML, Popovici C, Sevastre-Berghian AC, Dreancă A, Vicaș LG, Artemisia annua L.: Chemical characterization, in vitro antioxidant investigations and in vivo toxicity studies. Rev Chim (Bucharest), 2019; 70(6): 1893-1898.

27. Stan RL, Hangan AC, Dican L, Sevastre B, Hanganu D, Cătoi C, Sarpataki O, Ionescu CM, Comparative study concerning mistletoe viscotoxins antitumor activity. Acta Biol Hung., 2013; 64(3): 279-288.

28. Thorn CF, Oshiro C, Marsh S, Hernandez-Boussard T, McLeod H, Klein TE, Altman RB, Doxorubicin pathways: pharmacodynamics and adverse effects. Pharmacogenet Genom., 2011; 21(7): 440-446.

29. Tin AS, Sundar SN, Tran KQ, Park AH, Poindester KM, Firestone GL, Antiproliferative effects of artemisinin on human breast cancer cells requires the downregulated expression of the E2F1 transcription factor and loss of E2F1-target cell cycle genes. Anticancer Drug, 2012; 23(4): 370-379.

30. Weifeng T, Feng S, Xiangji L, Changqing S, Zhiquan Q, Huazhong Z, Peining Y, Yong Y, Mengchao W, Xiaoqing J, Wan-Yee L, Artemisinin inhibits in vitro and in vivo invasion and metastasis of human hepatocellular carcinoma cells. Phytomedicine, 2011; 18(2-3): 158-162.

31. Weydert CJ, Cullen JJ, Measurement of superoxide dismutase, catalase and glutathione peroxidase in cultured cells and tissue. Nat Protoc., 2010; 5(1): 51-66.

32. Willoughby JASr, Sundar SN, Cheung M, Tin AS, Modiano J, Firestone GL, Artemisinin blocks prostate cancer growth and cell cycle progression by disrupting Sp1 interactions with the cyclin-dependent kinase-4 (CDK4) promoter and inhibiting CDK4 gene expression. J Biol Chem., 2009; 284(4): 2203-2213.

33. Wu J, Hu D, Yang G, Zhou J, Yang C, Gao Y, Zhu Z, Down-regulation of BMI-1 cooperates with artemisinin on growth inhibition of nasopharyngeal carcinoma cells. J Cell Biochem., 2011; 112(7): 1938-1948.

34. Yang Y, Zhang X, Wang X, Zhao X, Enhanced delivery of artemisinin and its analogues to cancer cells by their adducts with human serum transferrin. Int $J$ Pharm., 2014; 467(1-2); 113-122.

35. Zyad A, Tilaoui M, Jaafari A, Oukerrou MA, Mouse HA, More insights into the pharmacological effects of artemisinin. Phytother Res., 2018; 32(2): 216-229. 